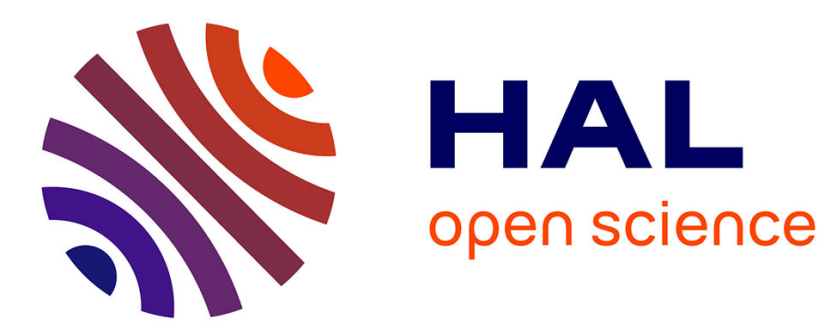

\title{
A mall for all? Race and public space in post-apartheid Cape Town
}

\author{
Myriam Houssay-Holzschuch, Annika Teppo
}

\section{To cite this version:}

Myriam Houssay-Holzschuch, Annika Teppo. A mall for all? Race and public space in post-apartheid Cape Town. cultural geographies, 2009, 16 (3), pp.351-379. 10.1177/1474474009105052 . hal00400561

\section{HAL Id: hal-00400561 https://hal.science/hal-00400561}

Submitted on 23 Sep 2010

HAL is a multi-disciplinary open access archive for the deposit and dissemination of scientific research documents, whether they are published or not. The documents may come from teaching and research institutions in France or abroad, or from public or private research centers.
L'archive ouverte pluridisciplinaire HAL, est destinée au dépôt et à la diffusion de documents scientifiques de niveau recherche, publiés ou non, émanant des établissements d'enseignement et de recherche français ou étrangers, des laboratoires publics ou privés. 


\title{
Cultural Geographies
}

http://cgj.sagepub.com

\section{A mall for all? Race and public space in post-apartheid Cape Town Myriam Houssay-Holzschuch and Annika Teppo \\ Cultural Geographies 2009; 16; 351 \\ DOI: $10.1177 / 1474474009105052$}

The online version of this article can be found at:

http://cgj.sagepub.com/cgi/content/abstract/16/3/351

\author{
Published by: \\ (S) SAGE \\ http://www.sagepublications.com
}

Additional services and information for Cultural Geographies can be found at:

Email Alerts: http://cgj.sagepub.com/cgi/alerts

Subscriptions: http://cgj.sagepub.com/subscriptions

Reprints: http://www.sagepub.com/journalsReprints.nav

Permissions: http://www.sagepub.co.uk/journalsPermissions.nav 


\title{
A mall for all? Race and public space in post-apartheid Cape Town
}

\author{
Myriam Houssay-Holzschuch \\ University of Lyon
}

Annika Teppo

University of Helsinki

\begin{abstract}
This article analyses post-apartheid public spaces through social and spatial practices at the Victoria \& Alfred (V\&A) Waterfront mall in Cape Town. Our empirical evidence suggests that these public spaces involve much more than just consumption patterns, as they sustain and support novel ways of asserting social identities in a new political situation. These changes are, however, quite complex and fraught with ambivalence. Consequently, we scrutinize how race is staged in that space, and how racial diversity produces various kinds of boundaries. We then argue that these urban practices lead us to an understanding of the precarious balance between private and public spaces. We propose the notion of 'publicization' - the process whereby private spaces acquire a more public dimension.
\end{abstract}

Keywords: Cape Town $\bullet$ mall $\bullet$ post-apartheid $\bullet$ public space $\bullet$ publicization $\bullet$ race

\section{Introduction}

C an social revolution be sustained in a mall? 'The end of apartheid in 1994 signified a considerable shift - not only in South African politics, but also in social relations. These new relations are expressed in new urban practices that are changing South African cities. In this article, we analyze post-apartheid urban dynamics against the backdrop of Cape Town's public spaces and, more specifically, its waterfront.

Social sciences have frequently used the South African case as a 'laboratory case' that allows theoretical issues to be tested and critical concepts to be assessed in real societal conditions. ${ }^{1}$ As an intrinsically spatial regime, ${ }^{2}$ apartheid has always been a source of interest for critically inclined cultural geographers. The implementation of racist beliefs and policies shaped spaces at the national, regional, and city level, producing what could be described as typical geographies of (racial) classification and socio-spatial control. ${ }^{3}$ Not only people were labeled members of specific racial groups, ${ }^{4}$ but South African cities, too, were strictly structured along racial lines. Legislation culminating in the 1953 Group Areas Act ensured that each group lived in separate neighborhoods, which differed greatly - Whites in pleasant, green suburbs and Coloureds and Africans in bleak townships. This segregation was extended to all levels of space, from public 
spaces and services to private homes, where provision was largely made for separate toilets for servants of color.

These geographical conditions still inform South Africa's cities: although the political regime was transformed into a democracy in 1994, and the pace of social change has been rapid, the inertia of spatial structures endures. Furthermore, spatial dynamics are subject to a 'time gap'5: inherited, even ossified, spatial forms designed to exert control over large parts of the population now accommodate democratic practices. In turn, these new practices have to imagine new ways of using apartheid space. The resulting discrepancy between spaces of control and new appropriations of space is a source of tension.

A further cause of spatial change in South Africa has been the state's loss of absolute power as a force shaping the cities. The present democratic dispensation allows the emergence or empowering of other agents. These include the market, local governments, various lobbies, and individuals. While having very different capacities to act, they all take part in the shaping of the cities. More specifically, since democratization, South Africa has increasingly experienced the influence of neoliberalism through the combined effect of national public policies and exposure to global forces. In particular, the economic policies pursued by the national government since 1996 have given both local and foreign investors a significant role in transforming the urban landscape. ${ }^{6}$

Then again, this post-apartheid evolution of South African cities has been used by scholars to initiate a more general discussion on contemporary cities, and to assess whether theoretical frames devised in the North fit cities of the South. Authors such as Robinson and Mbembe push the challenge one step further and use South African cities in their endeavor to 'writ[e] the world from an African metropolis ${ }^{77}$ or 'thin $[\mathrm{k}]$ about cities from a place outside the global core'. 8 'Thinking through' South African cities, as Robinson puts it, ${ }^{9}$ is what we attempt to do in this paper by focusing on Cape Town's currently reformed and redefined public spaces. We believe that an approach through public spaces first allows a fresh interpretation of what apartheid was and what its consequences are in present-day South Africa. Second, the very importance of public space during apartheid makes exploring its post-apartheid dynamics imperative. In turn, the South African case sheds new light on the notion of public space.

We base our analysis of post-apartheid public spaces on spatial practices at the Victoria \& Alfred (V\&A) Waterfront harbor renovation and mall: a space initially designed for the sole use of White, middle-class consumers. Our empirical evidence suggests that social and spatial practices there involve much more than just consumption patterns. Indeed, during the research, we uncovered the paradox of a privately owned space devoted to consumerism also functioning as a place where racially and socially diverse people exert their 'right to the city" ${ }^{10}$ - a privilege that is historically far from self-evident for the residents of Cape Town. Socio-spatial practices at the V\&A also sustain and support new ways of asserting social identities in a new political situation. The processes, interactions, and consequences of these changes are, however, quite complex and fraught with ambivalence, even paradoxes. Consequently, we underline the ambivalence of a (White) mall becoming mixed by scrutinizing how race is staged in space. We then argue that these urban practices lead us to an understanding of the precarious balance between private and public spaces. To better understand this balance, we propose the notion of 'publicization' - the process whereby private spaces acquire a more public dimension. 


\section{Public space and the apartheid city}

\section{(Re)defining public space}

'Public space' is a tricky notion as different disciplines give the term different and partially overlapping meanings. There are three prevailing interpretations of public space. ${ }^{11}$

First, public space has been politically understood as the metaphorical space of public debate. It thus reflects the vitality of a given society's political life. A vibrant public space is a manifestation of the strength of democracy, most notably through civil society and participatory citizenship. This definition, strongly embraced by French sociologists, ${ }^{12}$ stems from Habermas. ${ }^{13}$ Although his vision of public sphere has been criticized as constrained to a White, bourgeois, and male audience within very specific historical and spatial limits, ${ }^{14}$ we find this political perspective most useful for our attempts to understand public space. Cafés, the press, and the internet are the physical and virtual places where public space - in a political and metaphorical sense - can most often be found, even though it does sometimes take to the streets and demonstrates. In apartheid South Africa, the prevailing White hegemony aimed at excluding Africans from this political and metaphorical public space by denying them franchise and other basic rights of citizenship.

Second, public space has been characterized from a juridical point of view that defines public land - land owned by public authorities - as public space. According to this definition, streets, squares, parks, and gardens are public spaces. Taking this view, urban planners distinguish between private and public land on the basis of its ownership under what Nicholas Blomley has called a specific, capitalist 'property regime. ${ }^{15}$ Richard Sennett labels this dichotomy a pillar of modernity's spatial order. ${ }^{16}$ However, this definition needs to be historically contextualized: ever since Roman times, western jurists have consistently distinguished between public and private realms ${ }^{17}$ In South Africa, the White-dominated state owned a considerable amount of land in urban areas, which allowed it to dictate the shape of the city and to facilitate its racial control.

Third, and most importantly for our analysis, through its uses and the diversity of the people who frequent it, public space has been identified from a socialperspective. In this sense, it refers to a concrete place where people from all walks of life meet and interact with one another. The French sociologist Isaac Joseph has been particularly active in promoting this view. ${ }^{18} \mathrm{He}$ emphasizes that open access is necessary for a space to be public in this social sense. Consequently, social public space should welcome 'a plurality of uses or perspectives. ${ }^{19}$ Joseph especially underlines its multidimensional and theatrical quality: in social public space, people are simultaneously on stage and in the public. Joseph calls this special quality of social public spaces 'publicness.' More recently, Staeheli and Mitchell ${ }^{20}$ have theorized 'publicness' as follows:

[T] he quality of publicness - the publicness of space - seems to consist of the relationships established between property (as both a thing and a set of relationships and rules) and the people who inhabit, use, and create property. A key issue with regard to the publicness of a space is the quality of access, which in turn is established in part through property relationships. ${ }^{21}$

They have extended this view to put the question 'What is publicity?' at the heart of their project. In other words, '[w] hat shapes the ability - for differently situated people - to be in public? What are the conditions of possibility, in particular times and places, of public-ness? ${ }^{22}$ On defining publicity, they insist that that which constitutes a public, or the rules of access to a specific space, is an exercise of power. Consequently, publicity has no fixed or settled meaning: it fluctuates 
permanently, is even contested. Under the apartheid dispensation, access to public space and the social roles played therein were solely defined by race: a decision by the White minority power that was challenged by the anti-apartheid movement, most prominently during the 1952 Defiance Campaign, when non-violent protesters entered White-only spaces such as bars, post offices, benches, railway stations, etc.

The political, juridical, and social definitions of public space differ; they describe a variety of phenomena and/or spaces. Consequently, when referring to public space, it is necessary to indicate which of the three levels are involved: the political, as a space of debate; the juridical, as public property; or the social, as a space accessible to everyone. Furthermore, a space can be public at one of these three levels but private at another level. Gated streets are, for instance, still juridically public - they still resort under a municipality - but their social use is private. This complex, multi-layered understanding of public space is evident in Cape Town with its apartheid history.

\section{Cape Town, the city of unequal public spaces}

Cape Town was established in 1652 (see Figure 1). For most of its history it was essentially a colonial city utilizing slave labor; the established hierarchies later turned into the principles of racial separation. Officially, it became segregated in 1901 when most Africans were forcibly removed to Ndabeni on the outskirts of the city. ${ }^{23}$ At that time, race mattered, but class could overrule it: a person's wealth and family connections could undermine the importance of color when determining an individual's social position. ${ }^{24}$ Furthermore, there was no total residential segregation as mixed neighborhoods still existed. ${ }^{25}$ Consequently, people of color had access - albeit limited - to all the different levels of public space. Coloured Capetonians could still hold significant positions at the political level, as Dr Abdurahman and his daughter Cissy Gool did, by becoming city councilors. Streets in the city center - juridical public spaces - still bustled with people of all shades and hues. ${ }^{26}$ Socially, people could also mingle over color lines in specific spaces such as churches and cinemas.

The segregation of urban space in South Africa attained its most infamous elaborations during the apartheid era (1948-1994). ${ }^{27}$ The defining change that apartheid brought about was that it systematized segregation and extended it to all spheres of life. The apartheid regime claimed and controlled public spaces for Whites only. The regulation of public space was central to the apartheid system. All three levels of public space were targeted: the political, because hierarchies of power were established on the 'natural' order of racial groups rather than on democratic principles, thus excluding the majority of the population from the political realm. Cape Town Coloureds - who equaled Whites in numbers by 1948 - lost their political position in 1956, and Africans were denaturalized and given citizenship of the 'independent' homelands of Transkei and Ciskei. Juridically, the control of land was concentrated in White hands. The apartheid regime transformed existing, juridical public places, designing new ones as places of power and propaganda, erecting symbols of White supremacy such as statues and monuments celebrating the triumphs of the Afrikaner nation. Legislation also ensured that a social change occurred, as meeting and mingling with the racial Other in public spaces was largely prevented. Apartheid administration limited the use, and even the existence, of social public spaces by reserving access 


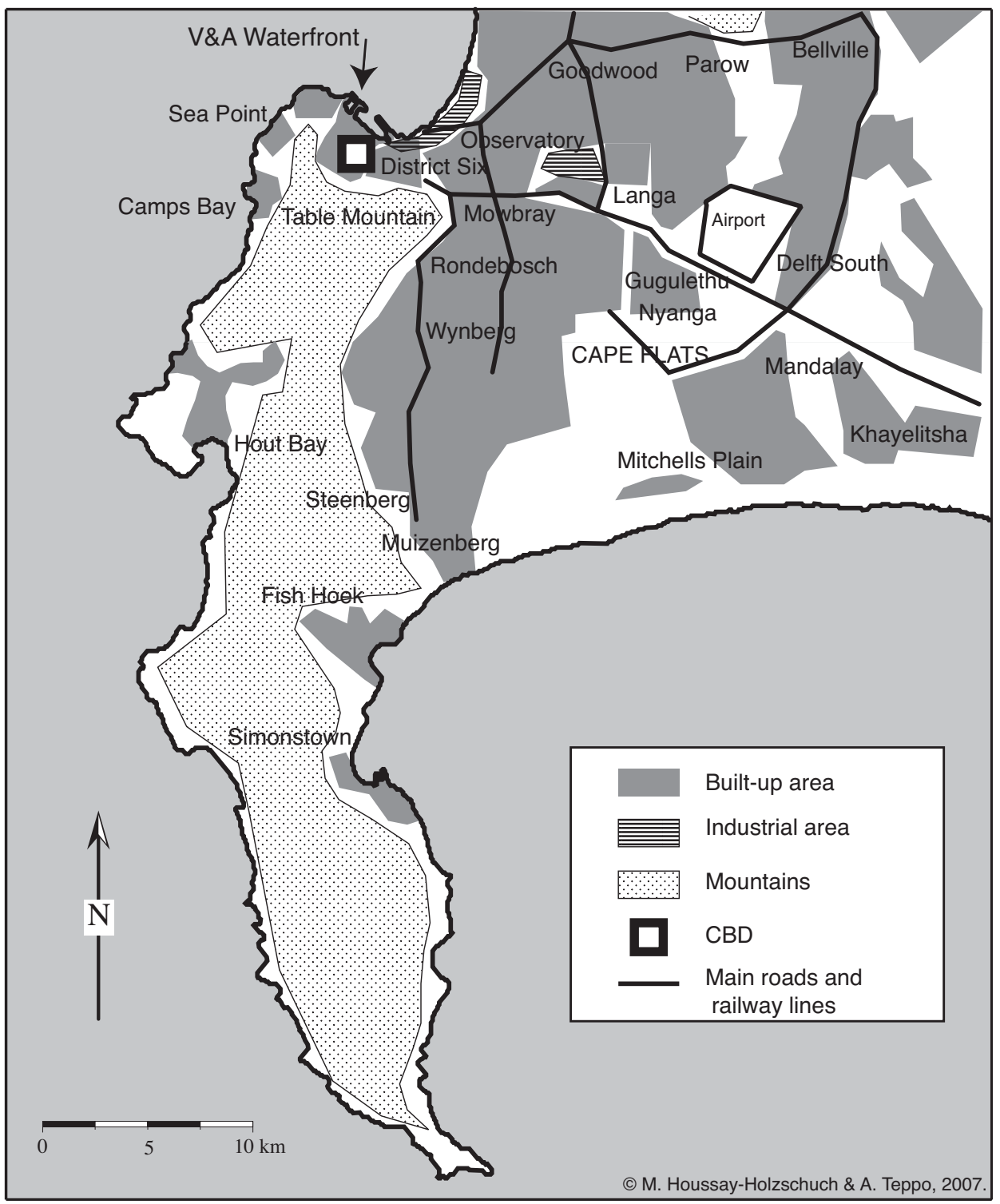

FIGURE 1 The City of Cape Town.

to them to Whites. 'Petty apartheid' worked on a microgeographic level, effectively separating transport, post offices, banks, theatres, and hotels - to mention but a few - along racial and racist lines. ${ }^{28}$ It even segregated beaches and parks, and wiped out those public spaces and residential areas unsuited for the White minority's highly sanitized concept of urban space - as happened in the infamous case of District Six. ${ }^{29}$ In other words, the very essence of public space - as democratic, civic, and accessible - was negated by the apartheid system. 
Yet, even during this concentrated effort to emphasize the supposed primordial inequalities between racial groups, the racially mixed nature of the public space in Cape Town was never completely eradicated. The suburb of Woodstock was, for instance, never completely segregated, and remained a 'grey zone' to the end of apartheid. ${ }^{30}$ 'There, the process of segregation was stalled for years as successive proclamations, contradictory decisions and indecisiveness, bureaucratic problems, local defiance, and practical difficulties in deciding within families who was Coloured and who was White brought it to a standstill. Also anti-apartheid movements contested, resisted, and even strategically targeted the state's public spaces policy in many ways. Potent, massive demonstrations symbolically claimed back the streets of the city center - juridical public spaces. During the 1960 anti-pass demonstration, African men in their tens of thousands, led by a youthful Philip Kgosana, walked up De Waal Drive from the townships to the city center - a march long remembered in the nightmares of White Capetonians. Another symbolic demonstration, the 'Purple Rain Protest,' was held at the very end of the apartheid regime, on 2 September 1989 in Adderley Street, in the heart of Cape Town. The purple dye sprayed by police cannons onto protesters led to city-wide graffiti proclaiming 'the purple shall govern.' Both the demonstration and the graffiti reclaimed the city's public space for the people. The protesters also attempted to establish non-racial social public spaces. The centrally located St. George cathedral at the top of Adderley Street, for example, became a hotbed of resistance under the leadership of Archbishop Desmond Tutu in the 1980s. Even if the movement's scope was at first limited, such actions did challenge the existing apartheid conceptions of public spaces. Progressively, the democratic movement conquered public space during apartheid's final years and this contestation culminated in the 1994 negotiated revolution. ${ }^{31}$

\section{Towards the emergence of new public spaces?}

The emergence of new public spaces in South Africa was linked to the democratization process, which provided access to public space for people whose presence had previously been illegal, and whose access had been restricted purely on racial grounds. Therefore, first and foremost, democratization had to be about giving more rights to African, Coloured, and Indian people. The first changes were recorded during the last years of the apartheid regime, and legally opened social public spaces to all races: for the first time since 1950, beaches and parks could officially accommodate multiracial visitors. Later, the transition years led to the repeal of the Group Areas Act in 1991. The path was now clear for racial desegregation in both public spaces and residential areas. Today, while places of residence are still largely racially segregated, ${ }^{32}$ places of sociability are slowly desegregating.

Political public space was democratized with the renowned first democratic elections of 1994. The electoral results put a democratic government of national unity, dominated by the African National Congress, in power. This meant that public property - juridical public spaces - was in the hands of a legitimate state and regulated by democratically approved laws. Nonetheless, democratization and desegregation are not the only developments that affect space in postapartheid Cape Town, even if they are among the most easily identifiable.

If a contemporary observer were to look at Cape Town from the top of Table Mountain, she would see urban spaces that still bear the imprint of apartheid ideologies and practices. 
Strict functional zoning separates the central business district (CBD), the harbor and industrial areas, and sprawling residential suburbs, which can range from the leafy, dotted with turquoise swimming pools, to the bleak, sandy, and windswept. With the benefit of 20-20 vision or binoculars, our observer would be able to distinguish some of the new, post-apartheid projects from among the residential suburbs: sprawling, low-cost housing developments and upper-class, gated communities. In the low-cost areas, even though the residents are now racially more heterogeneous and enjoy the full benefits of South African citizenship, their environments remain as monotonous as those of apartheid-designed townships. The neighborhoods are purely residential, with strict functional zoning compelling people to commute long hours to distant places of employment or commerce. Here, spatial fragmentation completes social fragmentation. The endless rows of cubical starter houses mainly accommodate a population that is still poor, still badly educated, and still African or Coloured. At the other end of the market, gated communities, mainly inhabited by Whites, have sprung up all over Cape Town - even if the pace of their development does not match those in Johannesburg. ${ }^{33}$ The surrounding physical barriers and the flocks of African security guards are material manifestations of the self-exclusion of the wealthiest. Distance or physical barriers isolate these new residential areas, different as they may be, and instead of contributing to the desegregation of the post-apartheid city, they further divide it. ${ }^{34}$ Thus, the remains of the apartheid city and the inertia of spatial structures ${ }^{35}$ are currently consolidated by new developments at both ends of the market to produce a very fragmented city. ${ }^{36}$

At the same time, many authors have pointed out that, as McDonald and Smith ${ }^{37}$ put it, "[o]ne of the most remarkable features of the post-apartheid political landscape in South Africa has been the rise of neoliberal thought and policy making.' In the South African context, Narsiah has defined neoliberalism as an increase in fiscal austerity, deregulation, and privatization. These changes are accompanied by the state's diminishing role and the transfer of competence to the private sector. ${ }^{38}$ This development is generally - though not always ${ }^{39}$ - associated with the 1996 policy shift from the Reconstruction and Development Program (RPD) to the Growth, Employment and Redistribution (GEAR) program. A macroeconomic strategy, this shift strongly emphasized economic growth, implying that such growth would fuel the much-needed redistribution and reduction of inherited inequalities. However, in South Africa neoliberalism is a multiscalar phenomenon, which has also informed urban policy making. ${ }^{40}$ Private investment, both foreign and local, is regarded as a key factor, and Cape Town increasingly attracts international firms ${ }^{41} \mathrm{New}$ business implantation, combined with the rapid expansion of tourism, produces what could be termed a neoliberal urban landscape.

Moving her gaze from the suburbs towards the city, our observer would then notice the kitsch architecture of GrandWest Casino and Century City, a new development hub that boasts a mall, a theme park, and the simulacrum of a Venetian canal, among others. ${ }^{42}$ Eventually, she will notice the numerous construction projects - be they commercial spaces, offices, hotels, or luxury condos in the making - in the foreshore area and CBD. ${ }^{43}$ The names of international companies and hotel chains, such as the Arabelle Sheraton Hotel, Vodacom Towers, and the Holiday Inn, on buildings prove that South Africa has indeed very rapidly joined the globalizing world since the end of economic isolation and international sanctions. Cape Town's urban spaces are thus subjected to two colliding influences: local - mainly socio-political, linked to democratization and the end of the racial order - and global, in other words, the consequences of capitalism, neoliberalism, and economic globalization. ${ }^{44}$ 


\section{A mall order?}

Cape Town is experiencing what can only be termed the decay of its traditional public spaces, together with the residential fragmentation mentioned above. ${ }^{45}$ In that sense, Cape Town's development converges with international urban dynamics. This global development is emphasized by the local changes described above. The streets, squares, and parks are no longer immaculately maintained by Africans for the exclusive use of the wealthy, White part of the population. The atmosphere has changed: public places are grubbier and certainly less safe. Since the demise of apartheid, criminal violence has replaced political violence. The occasional observer walking through Cape Town's Company Gardens during the late afternoon witnesses loitering tourists and relaxing office workers leaving the park to be replaced by the homeless, bergies. Indeed, most people do not walk the streets of Cape Town after dark if they can avoid it. The general feeling of insecurity is further fuelled by soaring crime statistics. ${ }^{46}$ Local stakeholders have reacted to this situation by either avoiding traditional public spaces - thus accelerating their decay - or privatizing them. This process has taken on various manifestations: public land, for example, has been privatized through gating and road closures, and private security companies are now largely in charge of public safety.

However, the decay and privatization of the traditional public spaces do not necessarily signify the death of public space as such, as new sociospatial forms are being invented. The private spaces of consumption and sociability, such as trendy cafés and restaurants, have undergone transformation - of which the revival of Long Street, which has become a bustling center of nocturnal party activity, is a good example. In addition to the CBD, pericentral areas such as Sea Point, Observatory, and Woodstock have been at the forefront of these changes, not least due to their history as racially mixed neighborhoods. Previously White malls, such as the Victoria \& Alfred Waterfront, have also started to welcome Coloured and African patrons.

Malls thus appear key spaces for analysing the way these different trends - neoliberalism, globalization, democratization, and desegregation - converge in South Africa, as well as their complex, localized, outputs. The international literature on malls has been expanding since the end of the 1980s, and is now profuse. ${ }^{47}$ Much of that literature points to the mall-as-simulacrum or 'pseudoplace, ${ }^{48}$ passing for public space even though it sanitizes the urban experience and is solely and very carefully designed for consumption. Analysts have thus tended to criticize the mall from a political point of view, highlighting the different ways it creates a safe bubble for the middle-class, and deploring the absence of political debate - the essential Habermasian dimension - in such a mock 'public space.' Staeheli and Mitchell, for instance, have shown that the political dimension of public space is biased and stunted by management practices in Syracuse's Carousel Center Mall. ${ }^{49}$ They have crucially emphasized the need to understand how the 'public' is constructed, who is excluded, and who is fighting for inclusion. ${ }^{50}$ In discussions on South Africa, observers have argued that the malls constitute new, globally 'imagineered,' 'regulated and repackaged' public spaces. ${ }^{51}$ Local academics have also drawn from the discourses of desire and nostalgia when discussing the malls. ${ }^{52}$ In addition, they have pointed out that the malls function as exclusionary, class-identity-building places. ${ }^{53}$

But do these spaces only operate in terms of global capital and its image-generating wizards manipulating the minds of the middle-class masses? Are they just palaces of desire, cradles of nostalgia, or sanctuaries that help Capetonians to escape from the grim realities of the present 
urban spaces? Could these global stages function as places of local contestations in a deeply divided society, or is the hegemony of global capital stifling these attempts?

Perceptive analysts like Goss have prompted us to reflexively question the very negative point of view on malls that is generally held: 'there persists a high-cultural disdain for conspicuous massconsumption resulting from the legacy of a puritanical fear of the moral corruption inherent in commercialism and materialism, and sustained by a modern intellectual contempt for consumer society. ${ }^{54}$ Hopkins goes further by extending the enquiry to what he calls 'the social functions of shopping centers' and asking 'whether the mega-mall represents a new form of social centre. ${ }^{55}$ In his 1991 article, significantly entitled 'West Edmonton Mall as centre for social interaction,' he shows that the mega-mall is indeed 'used as a place to mingle and socialize. ${ }^{56}$

The Victoria \& Alfred Waterfront, Cape Town's most emblematic mall, is undoubtedly the best place for our inquiry. The closeness of the harbor and the commanding silhouette of Table Mountain make the Waterfront an absorbing place (see Figure 2): it is cosmopolitan and African at the same time. This harbor rehabilitation, very much in the lines of James Rouse's festival marketplace, dates back to the end of the 1980s when the abandoned buildings and outdated quays were transformed into a pseudo-Victorian shoppertainment attraction for White Capetonians. ${ }^{57}$ The municipality of Cape Town's plans to redevelop the harbor began to be implemented when 'the then landowner of the Cape Town harbour, a state-owned transport corporation, Transnet Limited, established the Victoria \& Alfred Waterfront (Pty) Limited as a wholly-owned subsidiary company to redevelop the historic docklands.' In a classic publicprivate partnership, Transnet provided the land under a long-term lease, while the private sector

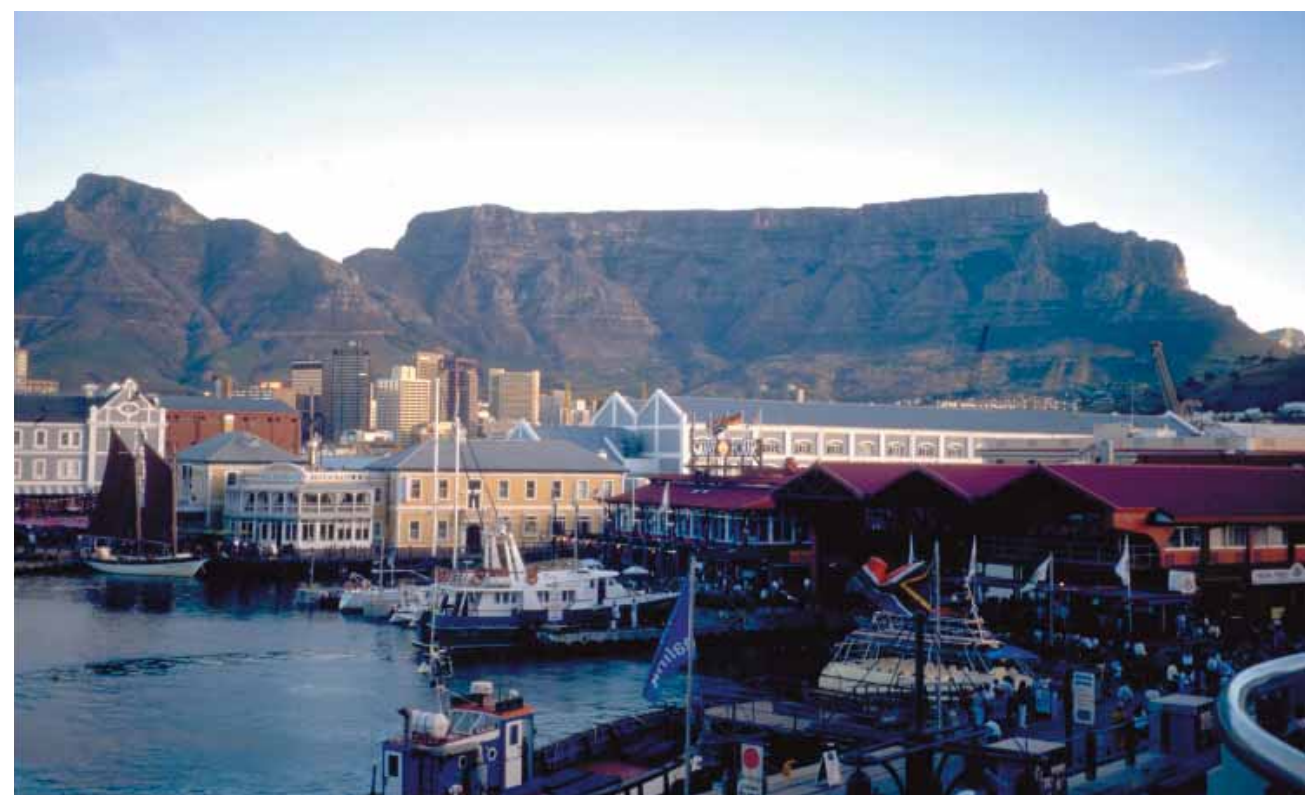

FIGURE 2 The picturesque panorama of Table Mountain provides the perfect background for the V\&A Waterfront. The proximity of the CBD allows for easy access. Source: Authors' picture, 1997. 
was in charge of its development. The construction work began in 1989, and was carried out in four phases. In 2006, Transnet decided to part with its share in the company, selling to the L\&R Consortium, which has British (London \& Regional Group Holdings Limited), South African (Black Economic Empowerment stakeholders), and Dubai (Istithmar PJSC, a part of Dubai World, held by the Dubai government) elements. ${ }^{58}$

Today, the Waterfront reportedly receives around 22 million visitors a year. There are several shopping complexes, the largest boasting $100000 \mathrm{~m}^{2}$ of commercial space, 68 restaurants, taverns, and eateries, 7 hotels, and 240 retail outlets. ${ }^{59}$ The entertainment facilities include two cinema complexes, the Two Oceans Aquarium, and the South African Maritime Museum (see Figure 3). Various sightseeing tours and cruises depart from the Waterfront. Most notably, the Nelson Mandela Gateway to Robben Island, the only access to the infamous prison turned into an internationally acclaimed museum, adds to the sense of history integral to the Waterfront.

The place as a whole is appealing to visitors because it is reminiscent of a mythical urban center - old but lively. This impression is the result of a variety of spatial elements, as several phases of renovation and construction have produced a composite space after almost two decades. Victorian warehouses have been transformed into a shopping mall, while their restored facades, brightly painted, still gaze upon the piers. The food court, partly shaded by arcades, connects the inside mall with the outside promenades and the amphitheatre. In addition, fishing boats, renovated historic sailing boats, and passing ships stopping for repairs confirm the Waterfront's status as a working harbor. In other words, designers have combined the interior model of the 'traditional' city center with the exterior model of the 'local and patrimonial. ${ }^{60}$ This reference to the local and patrimonial is further elaborated by a wide variety of attractions and entertainments that make the Waterfront a popular venue. There are bands, street performers, singers, theatre groups, fire blowers, contortionists, and clowns offering entertainment on the promenades and in the amphitheatre. The managing company organizes and selects them, thus seeking to control the ways in which this lively public space is constructed. It also ensures that top-notch security arrangements are firmly in place. ${ }^{61}$

The Victoria \& Alfred Waterfront conceives, and indeed markets, itself as both international (globalized) and local (African and Capetonian). It hopes to appeal to domestic and international tourists, as well as to local urbanites of all colors. In other words, it places itself at the core of the converging trends of neoliberalism, globalization, democratization, and desegregation that we mentioned earlier. Assessing this bold claim by means of empirical evidence is not, however, only about testing the success of such a marketing image. Far more interestingly, taking a closer look at the 'public' who actually come to the Waterfront, trying to decipher how this public has been constructed, and whether it has changed with democratization, means, in Lefebvrian terms, shifting the gaze from an 'abstract space' to the 'spatial practices' that it hosts. ${ }^{62}$

We thus return to the idea of the mall as a center for social interaction as presented by Hopkins in respect of West Edmonton mall, and pose a further question: can a mall also function as a center for social interaction in a deeply divided, post-conflict society and, if so, how? We have chosen to focus our analysis mainly - though not exclusively - on race. Social interaction and publicity require a confrontation with the Other; that is, the racial Other in the South African context. Indeed, as Seekings insists, ${ }^{63}$ South African 'society remains highly racialised'64 and 'there remains a close correlation between official apartheid-era classification, post-apartheid self-classification and post-apartheid classification by other people. ${ }^{95}$ Elaborating on what he calls 'the continuous 


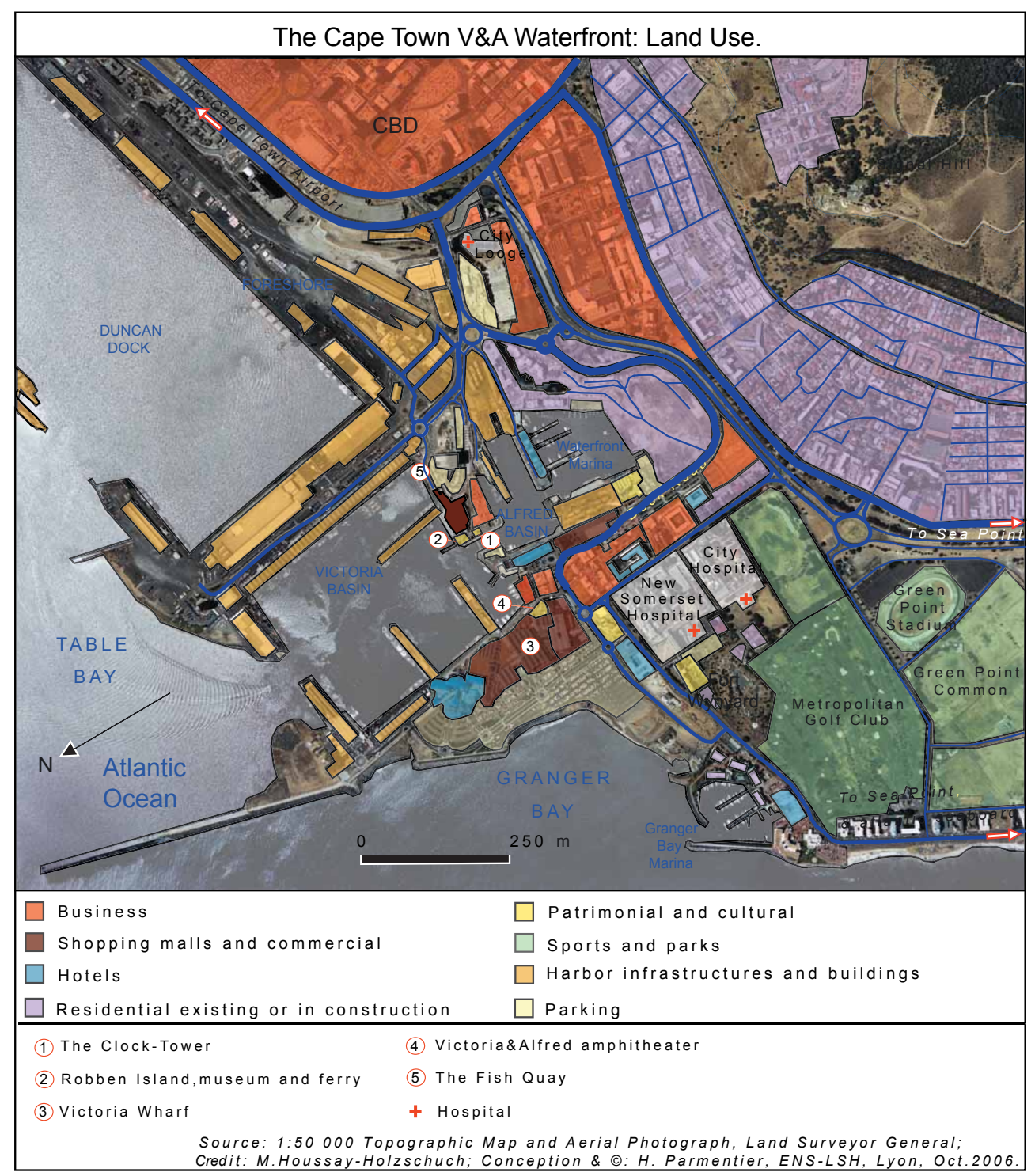

FIGURE 3 Plan of the V\&A Waterfront. Source: Aerial Photograph, Surveyor General, 2001, and http:// www.waterfront.co.za.

salience of race,' he shows the continuity of racial division, and its inherently social rather than economic nature. A majority of South Africans live in areas segregated from other 'races' and even elementary education is still largely divided along the old racial lines. ${ }^{66}$ Interracial contacts are not only limited but are also wrought with difficulties. Louise Vincent ${ }^{67}$ notes that even where interracial encounters have increased, they do not necessarily lead to greater racial integration, as they often occur within a context of unequal power relations. 
We relied on a set of methods to empirically assess how the Waterfront public is racially constructed, divided, and diversified. We employed an ethnographic approach, conducting participant observation at the Waterfront since 1994, keeping field diaries, hanging around, and talking to people. Since 2001, we have gathered more than 50 questionnaires, which include structured interviews with patrons, shop managers, security guards, and various stakeholders. ${ }^{68}$ In order to understand the racial and temporal patterns of the V\&A's frequentation, we counted the patrons on various occasions. Exploratory countings were first done in 2000, 2001, and 2004. Systematic countings were subsequently done between February and April 2005. A specific location (the Victoria Mall's seaside entrance) was chosen and the passers-by were counted within a 15-minute period. This was repeated every hour (from 10:00 to 18:00) throughout the week and weekend. Simultaneously, the patrons counted were categorized racially, using the local criteria - in other terms, we tried to assess what racial identity they would be (forcibly?) assigned by their interlocutor during any kind of interaction with strangers. While aware of the political and ethical difficulties of this categorization process, we argue with Seekings that social interaction at the V\&A occurs within this framework. How people define themselves, racially or otherwise, counts much less than how they are defined by others - a consequence of the anonymity of interaction within public space. We relied on our long field experience in and around Cape Town and our equally long study and use of South African racial categorizations to ensure correct classification. ${ }^{69}$ South Africans routinely assign a 'race' to the people they meet, basing this assessment on phenotype: first on skin color, then on facial features (e.g., Capetonians recognize several different types of 'Coloured' faces), language (if overheard), accent (the English and Afrikaans accents of 'Coloured' Capetonians differ greatly from those of Whites and Blacks), 'loudness,' bodily attitudes, clothing (a Muslim scarf, or a Xhosa doek), etc. It is probable that we occasionally misclassified, but we also know that South Africans get it wrong from time to time, which underlines the fact that the idea of 'race' is socially and historically constructed, as well as endlessly mutable. For a majority of South Africans, the racial categories are still as real as ever, and many still believe that there are some biological, essential properties that differentiate people. ${ }^{70}$

\section{How to change a white space?}

Seen through the eyes of a local critic, the Waterfront could present a prime example of what architect Jonathan Manning ${ }^{71}$ has described as a post-apartheid private urban space linked to a display of wealth and architectural racism, which is 'about form fetish and imagery rather than about creating space to accommodate social interaction.' Manning denounces the style of many present-day South African buildings as lacking an African cultural heritage, and rather evoking European aesthetic fantasies from ancient Greece or Imperial Rome, rural England, Tuscany or Provence - in short, they mimic quintessentially White spaces. The Waterfront could be a prime case in Manning's point: not only its colonial architecture could produce such spatial fantasies and simulacrums, but also the very history of the place is White. A colonial harbor, it symbolizes the European political domination and subsequent economic power. Buildings such as the quay where prisoners were sent to Robben Island, the Breakwater Lodge hotel, once a 19th century prison, still dot the landscape. The architects and designers in charge of transforming the harbor 
into a place of leisure were as White as the customers they targeted. Indeed, until shortly after 1994, the Waterfront used to be an exclusively White leisure area, ${ }^{72}$ and far from welcoming for the shoppers from Black townships, who were even racially harassed in 1993 and $1994 .^{73}$

Local geographers Ferreira and Visser do not squarely address the issue of the Waterfront as a White space, but the issue looms large, if implicit and unrecognized, in their positive presentation of the place as the 'South African Riviera,' which 'has become a 'special space' for whites' and an 'escape from the realities of a post-apartheid and increasingly Africanizing Cape Town. ${ }^{74}$ Ferreira and Visser explain how exceptional Cape Town has been and is in terms of its history and demographics - a Coloured and White city more than anything, with no real place for Africans. They hope that the new Dubai owners will add a layer of 'African identity,' while simultaneously pointing out that the Whites and Coloureds have 'a justifiable claim' to the heritage of Waterfront and calling it the 'White man's playground. ${ }^{, 75}$

In order to interrogate both of these local perspectives on South African public spaces, we studied the actual social interactions and practices at the Waterfront. Are the categories of class and/or race really contested there and, if so, how? Only sufficiently recent empirical data could help us answer these questions.

Our countings show a dramatic change in visitor profiles over time. Indeed, the Waterfront was designed by (upper middle-class) Whites for (upper middle-class) Whites, and has long been a hostile place for anyone else. In 2005, however, the figures began to reflect a very different reality (see Figure 4). Coloured and African Capetonians, even if they live in the far-off townships of the Cape Flats, were turning up in growing numbers. Whites were still overrepresented, although this could in part be explained by the presence of international tourists, mainly from the UK and Germany. ${ }^{76}$ In the 2005 counting, more than 60 per cent of visitors on Saturday afternoons were not White.
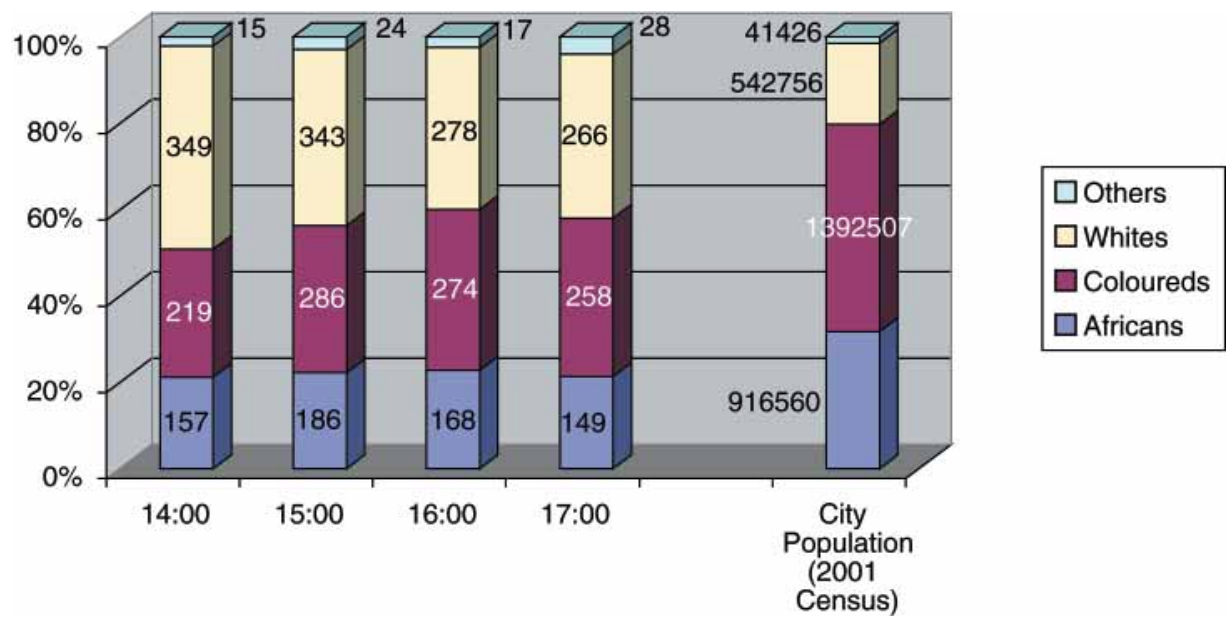

FIGURE 4 Breakdown of V\&A visitors on Saturday afternoons by race. Source: Authors' countings February-April 2005. 
In addition to racial desegregation, the Waterfront shows strong signs of social heterogeneity. The majority of the visitors interviewed can still be described as middle-class. However, our questionnaires show that one-third of all visitors belong to the lowest income categories. Other indicators support these findings; for instance, approximately 50 per cent of the interviewees used public transportation to travel to the Waterfront. ${ }^{77}$ This is indeed a strong class marker in South Africa, where anybody who can possibly afford a car owns one.

This racial and social heterogeneity is further emphasized by the fact that the Waterfront is public land, even though the buildings themselves are private. Consequently, managing the place is a delicate balancing act between sometimes contradictory legislation concerning private and public spaces. This becomes particularly evident in the ways security guards constantly negotiate with street children and bergies, attempting to limit their presence at the Waterfront.

They're a nuisance. They disturb people. But if they do nothing, we can't do nothing; we struggle with them all the time. (Security guard) ${ }^{78}$

The crowd at the Waterfront has brought color and bustle back to the old harbor. One can see the emerging African bourgeoisie, also called buppies (Black urban professionals), wearing locally designed but award-winning Afro-chic, Italian sunglasses, and Nokia cell phones. They mix with African maids with berets and blue-collar workers dressed-up in leather jackets and woolen caps. Respectable Coloured Muslim families mill around, mothers and daughters wearing headscarves, proud fathers holding their sons' hands. The multiracial youth follows international fashion, but with slight nuances and variations that reveal the racial and social group with which the wearer identifies to the initiated in-crowd. A quintessential group, upper-class housewives, is often jokingly referred to as kugels. Originally, they were overprivileged Jewish ladies with long artificial nails, glittering jewelry, and Dynasty-inspired outfits and hairdos. The term was later extended to any middle-class woman wearing enough bling. International tourists clad in a variety of holiday gear rub shoulders with business people, office clerks, and the occasional cultural geographer or anthropologist - in short, basically anyone.

Why, then, do all these very different people flock to the Waterfront? The first, obvious, answer would be that they come to the Waterfront for what it was built for: shopping. The Waterfront as a whole was obviously designed as a commercial space, as all its activities are geared towards consumption. Even when the amphitheatre hosts a performance of gumboot dancers, the purpose is to tempt people to stay longer and spend more money. However, the activities offered by no means cover all visitor practices. People often simply walk down the alleys, stroll, look around, and rest (see Figure 5).

I come here every week. I do nothing. I just look around; move around. It's my pastime. It's nice and free. (Retired Coloured woman, 87)

Remarkably, 40 per cent of the interviewees maintained that they had spent no money at the Waterfront. They insisted that they had come to enjoy the place and nothing else - South African flaneurs. What is more, a sizeable part of the money spent (35 per cent) was devoted to social activities such as having a drink with friends, sharing a meal or going to the movies. Interestingly, our observations are very similar to those Hopkins made in the Canadian West Edmonton Mall: 'WEM is often used more as a place to wander, to socialize - to mallinger - than simply as a place to make purchases and quickly depart. ${ }^{, 79}$ 


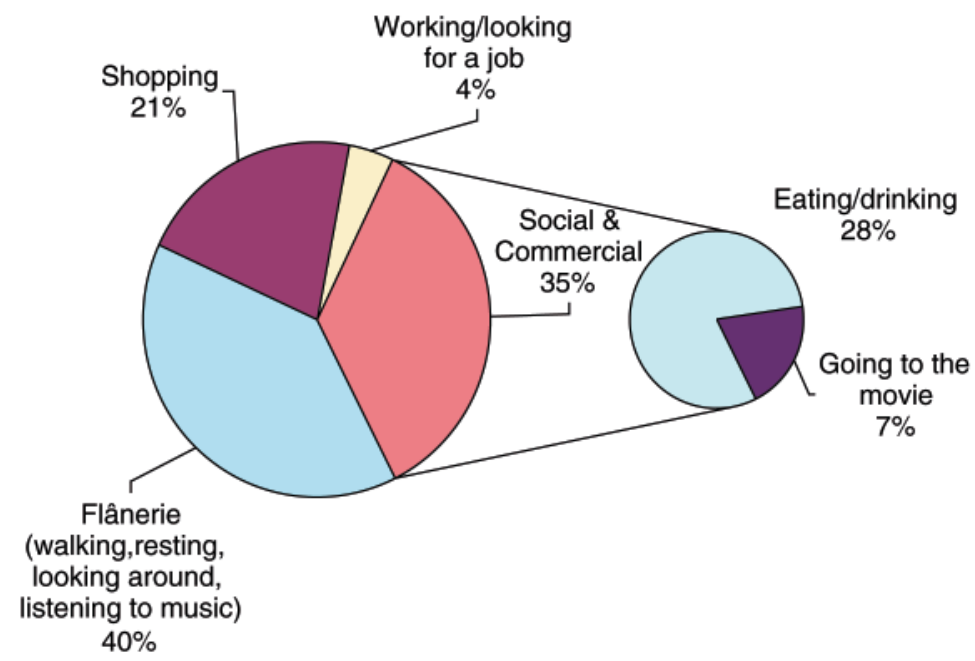

FIGURE 5 Visitors' activities at the V\&A Waterfront. Source: Authors' interviews, February-April 2005.

The Waterfront also contains an element of the extraordinary as Black South Africans with their history of isolation and townships of deprivation enjoy the aesthetic experience and international buzz.

It is the most beautiful place I have ever seen. (Coloured printer, 41)

I like the entertainments, like the music; and also you can see people who are in TV, you can see celebrity, famous politicians. (African security guard, 27)

I like to look at the foreigners. (Coloured male, 19)

In the interviews, it also became obvious that the patrons and shop managers of V\&A perceived the place differently. When asked whom they thought the mall was for, some restaurant and shop managers emphasized the equality of the mall: 'everyone can come,' and 'all types of people can come.' Others pointed out the exclusivity of the place: 'it is not for the people from Khayelitsha' (Cape Town's poor, African township), or 'it is for people who have money to spend.' These answers contrast with Waterfront patrons' responses, who, while clearly aware of the high prices in the mall, were nevertheless unanimous regarding the heterogeneity of the crowd: 'all kinds of people,' 'many tourists,' 'everybody,' and 'a multiracial place.' The wealth - or lack thereof - of other patrons was not considered important in their answers. The interviewed patrons did not complain about the high prices - as noted, many of them were not really shopping. Instead, they emphasized the sociability and pleasure of being there. Looking at people and things, they told us, was their main source of pleasure and an important activity. Thus, the main answer we elicited from them was a rather circular one: despite all the shopping opportunities, the entertainment, and gaudy architecture, the main amusement that the Waterfront offers is the people there. It is the place to see and to be seen. Everyone is on display in this public urban space's multiethnic show. 
I like this place also because you can meet different people and you get to know them. (African security guard, 33)

The young people, they come to stand and look. They want to look pretty, and fashionable ... It is an extroverted place. (Coloured male, 19)

The Waterfront functions as a live stage and a social theater. ${ }^{80}$ Many people are engaged in reciprocal performances: they both enjoy the crowd and want to stand out from it; like classic flâneurs, they want to watch and be watched. They are both the public and the actors of a novel social play. The old Coloured lady looking for an international atmosphere and experience is fascinated by the tourists from all over the planet, while the German traveler, who would not dare enter a township, enjoys looking at the locals, taking in the African flavor of the place.

The Waterfront as a social public space has thus undergone a major desegregation process: its actual public has been reconstructed as much more inclusive, both racially and socially. We will later suggest that this process can be described as social 'publicization.' Here, a White space has become more accessible, that is, more (socially) public. But this very real and striking change does not always occur smoothly. The Waterfront is reminiscent of a giant container where people are on display or, in Morris's words, where 'the crowd itself becomes a decorative feature of the shopping centre's performance', ${ }^{81}$ and where urban sociability can flourish. It is cosmopolitan and African at the same time.

\section{Tenacious boundaries}

Nevertheless, the Waterfront also remains a White space, or a space of whiteness, and critical race theory can help us understand what this means to the new patrons. As a behavioral and aesthetic norm, whiteness has been hugely influential in South Africa. The theorists of whiteness studies have pointed out how invisible and taken-for-granted whiteness can easily become, and how it underlines the expectations of what is socially acceptable, especially in colonial countries. ${ }^{82}$ Annika Teppo has also pointed out the sheer tenaciousness of the boundaries of whiteness, and the ideal state of being a good White, which everyone, including people of color tried to achieve, whether passing for White - as was once commonplace - or not. ${ }^{83}$ During apartheid, a Coloured person found it much easier to pass for White as soon as he or she could adjust his/her habitus to be respectable enough. This respectability included being clean and neat, wearing good clothes and speaking in a manner considered 'civilized.' Indeed, one of the pet peeves of White South Africans is to complain aloud about how loud and obnoxious people of color are. In public places such as the Waterfront, a proper behavior is a 'White' behavior. Loudness is frowned upon, and White aesthetic ideals are presented in every shop window. Whatever 'blackness' means in South Africa, it is still the suppressed Other with all the negative consequences this has in respect of social interaction and racial mixing. Nevertheless, these boundaries are not easily expressed aloud. If South Africans have become careful at something, it is voicing their opinions about such a charged issue as race. Yet, under the surface of polite words, many heated emotions simmer. The language used when speaking about racial issues is veiled, almost coded. Strategically placed silences are often as informative as that which is said aloud.

It is slowly changing. It is not like before. (Black man, 48) 
Before the end of apartheid, black people were not allowed to go. Anybody can't come, only whites. Now you can go into any shop. (Black security guard, 27)

[Voice down] Do you see all the Blacks here? If they won't be here, it would be dead. (White retired male, 84)

The last quote points to the very ambivalence of the racial diversity experience. For this old White man, strict segregation has been a way of life for decades; mingling with the racial Other discomforts him enough to lower his voice, even though he approves of their presence. The oppression of the past, even when seen in the positive light of a much better present, is still there and affecting people. In many interviews, the seemingly cheerful tone of the answers was not far removed from painful memories.

Charlotte Lemanski has defined Cape Town as a 'city of exclusions' ${ }^{84}$ Indeed, in addition to the racial norms generally affecting and segregating the society, the Waterfront demonstrates that racial boundaries are simultaneously porous and persistent at several levels. First, the striking racial heterogeneity of the Waterfront public can be broken down into finer temporal patterns, also telling of the complexity of racial mixity. Waterfront visitors have changed dramatically over time, with more Africans and Coloureds - who were virtually absent in the mid-1990s arriving. ${ }^{85}$ This trend continued between 2001 and 2005, with a steady increase in African and Coloured patrons. There are also differences in frequentation over the course of the week. Whites patronize the Waterfront all week long, whereas Africans and Coloureds are less represented on weekdays (around a third of all visitors), but arrive en masse on Saturdays and Sundays. Whites tend to come in the morning and remain throughout the day, while Coloureds and Africans arrive later. Interestingly, different groups do not exclude one another, and there are no signs of 'white flight,' as the Whites do not leave the place to Africans in the late afternoon, but coexist within the same space. The high number of Whites during daytime can possibly be explained by the number of foreign, mostly White, tourists, who comprise roughly one quarter of all visitors. Furthermore, South African Whites enjoy much more leisure time than other racial groups ${ }^{86}$ : housewives and students are, for example, more likely to be White. Conversely, working-class Coloureds and Africans are, well, working during the week. Thus, Saturday seems to be the day of choice to enjoy the Waterfront, as Sundays are generally spent between the church, family lunch, and home. The variations in frequentation patterns are not only explained by the racial groups' differences regarding leisure time, but also by the structure of the former apartheid city itself. Africans and Coloureds live on the periphery of the city, can mostly not afford a car, and have to use the inefficient public transport. Consequently, they need more time to travel to the Waterfront, and arrive later.

Second, there are also concrete, spatial racial boundaries with their exclusions and inclusions. In the interviews, the space of the mall was perceived as divided between the inside and the outside, reflecting the difference in property rights. The inside of the mall, in particular the second floor, was more likely to be mentioned as a place for wealthy people, with somewhat more restricted access: there was fun and games for all regardless of color, granted, but only for those who could afford it. By contrast, the outside - the quays and terraces, and relatively inexpensive fast-food counters - was described as a free and safe urban space for all - a rare treat in Cape Town.

Coming back from the Post Office in a quiet, slightly gloomy alley on the second floor of the Victoria mall. I pass select shops where designer clothes wait for foreign money. Armani Jeans are just a bit further. The escalator takes me 
down to where I enter a happy hubbub, where a mixed crowd bustles between the fake Africana of the souvenir shops and the weekly shopping at Pick n Pay. Under the light of a glass roof, the elaborate scents of Crabtree \& Evelyn mix somewhat uneasily with the syrupy aroma of Sweets from Heaven. Badly in need of refreshment, I head for my favorite spot, the quay terrace of the San Marco café. As soon as I set a foot outside, the atmosphere changes: an unmistakable African sun blinds me, and I bump into a gathering. A mixture of South African-style gospel and soul music thunders through the loudspeakers: a show is going on at the amphitheater. Fighting my way forward, I spot three African female singers, swinging in their long, pastel dresses. The crowd is amazing: the amphitheater is crammed, of tourists, locals, young, old, Black, White, Coloureds, Indians, even Filipino sailors, men, women, etc. Dozens of others have climbed the outside stairs and colonized the balcony to watch the show from a vantage point. On the other side of this glass door, Armani Jeans remains as quiet as ever. (MHH, Field diary, April 2004)

This outside pleasantness is highlighted by the scenic environment - indeed, many of the patrons we interviewed mentioned the docks and sea breeze as attractions. The outside space was actually the one point that had even the most critical interviewees compare the Waterfront favorably with other malls.

I don't shop here. It is expensive, pretentious. It has nothing to offer to me as an African man. It aggravates stereotypes about what I should wear, who I should be. Only one exception: the Jazz place and Nelson Mandela Gateway. It is history. (African male, 30)

This is a mixed statement. In fact, the expressed dislike of high prices and pretentiousness, the felt loss of dignity that the interviewee presented, points to another issue. After the long era of complete exclusion, after being largely confined to the townships, all Black South Africans are definitely not at home, and even experience discomfort here.

Part of the reason for this discomfort is the invisible racial and social lines etched on the Waterfront landscape: the fine divisions between the outside and inside, and weekends and weekdays are telling. Caused by the constant encounters between White and non-White people, these lines bear a resemblance to the segregation Arun Saldanha saw emerging on the beaches of Goa, India. ${ }^{87}$ There, the hippie subculture excluded all but White visitors, pushing Indian tourists and locals to spatial and temporal margins in, for example, bars or at all-night 'open' beach parties. In Goa, the viscous and versatile boundaries of whiteness were subtly, but decisively, drawn with ever-shifting practices, phenotypes, and codes of conduct. Despite its similarities to the processes Saldanha describes and largely due to its different historical, political, and racial context, the process of making race at the V\&A results in different outcomes from those in Goa, as it is cautiously inclusive rather than exclusive. While there are concrete spatial and temporal divisions, they are hardly as compelling as in Goa. Besides, for those Whites who detest racially mixed public spaces, there are always other, 'more White' malls such as Tigervalley in Durbanville in northern Cape Town.

Third, there are the invisible social boundaries, which are perhaps the hardest to detect. The ways they are navigated and negotiated through interaction are only momentarily visible. Nevertheless, we should proceed with caution, not over hastily prescribing what kind of interaction is indeed meaningful and what not. As various observers have shown - be they journalists, novelists or social scientists - the signs that allow one to track social changes in South Africa are often quite elusive and expressed in the idioms of attitude, style, language, or even consumption. ${ }^{88}$ In seemingly casual interactions, gender and youth identities, or a race/class identity nexus are subtly maneuvered. At the V\&A, a myriad of functional exchanges occurs successfully between 
shopping Whites and working Blacks, or vice versa. However, actual conversations seldom happen over color lines: it is as if invisible glue holds people in their predetermined places. South Africans, who are very capable of engaging in hearty and deep interactions with strangers, experience discomfort when doing it across racial lines, and therefore need a common purpose of some kind.

A not so negligible number of single African males sit on the steps, watching a temporary attraction: in the open space between the amphitheater, the food court, the select Vaughan Johnson wine shop and the paths to other shops, a trampoline has been set up, as well as elastic cords that are attached to a wide metal framework. The event seems to be sponsored by Adidas, as a giant cardboard shoebox sports the brand next to the installation.

I briefly stop in my tracks: screams of delight mixed with parental interjections cover the usual racket of the seagulls. Something fun is clearly happening. Under the supervision of their parents, children of all races climb the trampoline: a Coloured girl, wearing a Muslim scarf, happily jumps and bumps in the air into a Coloured boy and a White boy. An African child waits for his turn, and replaces the White boy on the trampoline. At the same time, a pictureperfect little blond girl, with long curls, screams with delight as she is thrown into the air by the Coloured attendant safely harnessed to the elastic cords. Her White mother joins in the happy screaming, as the girl bounces up and down. Parents of all colors line the place, and proudly watch - side by side - their children playing - side by side, or even together, on the trampoline. Parents exchange friendly words, point at each other's children, and enjoy a happy moment together. (M.H.-H. Field diary, February 2008)

The Waterfront management had carefully constructed this event, no doubt to foster a family atmosphere and encourage people to stay longer. Participants in the event would be tired from all the jumping and screaming, and would perhaps want to enjoy a refreshing drink at the nearby food court. Customers already eating their Kentucky Fried Chicken, their fries, and ice creams sat down on the benches and steps to enjoy the free show and the children's laughter. They could go back to the counter to order more, as their own children took their turn on the trampolines. The Adidas logo had been seen and associated with a happy, rare moment. This entertainment was definitely manufactured to encourage consumption, but it nevertheless created a social microevent that was unthinkable, even illegal, under apartheid. For the people involved, it was a passing but equal and meaningful encounter during which interracial contact was free of tensions. The children provided a perfect excuse and topic to share; the occasion was temporary, the encounter ephemeral, and devoid of any kind of commitment (for instance, of sustained relations between the participants).

The racial, spatial, and temporal boundaries are part of the display of difference. This display does not exist without ambivalence. Not only is this a bold and attractive show of multiculturalism, but the differences displayed also remain evident, sustained, and collectively understood, even if they are less sharply defined than they used to be. There is still the element of separateness at play, and the line is drawn in personal relations. White, Coloured or Black South Africans seldom visit each others' suburbs. It is thus only logical that multiracial groups are still a rare sight in the corridors of the mall, or at the tables of local restaurants.

In the end, the main Waterfront show is shockingly simple: the peaceful coexistence of people of all colors. This was also reflected in the questionnaires when the patrons were asked if they thought the Waterfront reflected the New South Africa.

Yes, because all the race groups come here. All races actually come here for entertainment. (Coloured supervisor, 41) 
Yes, because you can see all kinds of people and not one who dominate. (Coloured student, 22)

I never cross any incidents here. People are well behaved here. (Coloured driver, 60)

Yes, it is quite true because everybody come to Cape Town. They can enjoy themselves. There is no fighting, no trouble. It is nice and quiet. (Coloured pensioner, 87)

The previously exclusive White man's playground has become a 'glocal' stage where South African tensions and issues are presented in a cosmopolitan setting. For the tourists, the show is being close to the 'real' Africa. For the locals, it is being part of a multiethnic, multiracial crowd. Yet, there are limitations to the racial mixing, and the ghost of apartheid's logic of separateness hovers in the corridors of the mall. Will this remain? Other ethnographic evidence points to the tentative development of a sociability of a more peaceful and equalitarian kind with the Waterfront acting as the 'cosmopolitan canopy' that Elijah Anderson identified in Philadelphia's Reading Terminal Market, 'where a diversity of people can feel comfortable enough to relax their guard and go about their business more casually. ${ }^{89}$

While the trampoline playground temporarily offered such a smaller canopy-more permanent ones are being established by the café society - as described by Laurier and Philo - that is forming at the V\&A Waterfront and elsewhere in Cape Town. ${ }^{90}$ These cafés, in Europe as in South Africa, provide a quasi-theatrical performance by baristas: de-anonymizing and a light mode of being together. At these cafés, aspects of cosmopolitan and local identities are combined, and raised as local issues. Since the ambience and spatial arrangements of a café can encourage high sociability and social mixing, established and often quickly-drawn boundaries - here, racial boundaries - are constantly tested and pushed, as they are porous and permeable, and do not always constitute barriers.

The ambience in this café feels like a piece of Africa where everything is fine-tuned as not to remind one of the surrounding Dark Continent. Yet, the physical surroundings turn out to be calculatedly European. This applies to the furniture as well: all chairs and tables are very high-tech, minimalistic, stainless steel and pale wood. The people serving are Black, very friendly, while most customers are White. Menus are in Portuguese and the snacks are also of that ethnic persuasion. The coffeehouse is very open, in the corridor of the mall, imitating a European café. The chairs are all turned towards the corridor, which plays the role of the street: this is where the theatre is, this is the scenery you should be enjoying. I order coffee, and the clerk bellows my order out loud in a manner which makes me giggle uncontrollably, as the other guys preparing coffee respond to his shout in thundering unison. I receive my coffee very quickly from an equally noisy guy at the other end of a counter. All the raucous, happy bustle and fuss about one puny latte is atypical of South African restaurants, which usually pride themselves on being subtly European. It has also put me in a happy, buoyant mood. The African barista misinterprets my grin and boldly asks me out, not the least afraid of my whiteness, merrily crossing all sorts of boundaries. (A.T. Field diary, November 2007)

Cultural boundaries are thus not made irrelevant by globalization but produce new forms of distinctiveness and identity politics. ${ }^{91}$ In social interaction, these boundaries, be they racial or cultural, are constantly tested and reordered. The V\&A Waterfront offers a particularly good background for this.

But why? The racial, spatial, and temporal boundaries - all the obstacles a Black person has to overcome in order to spend some time there - are deeply rooted in South African history. The strange cultural frame of reference, the fear, and the invisible wall felt when coming into a 'White area' might prevent Black South Africans from entering. However, there are reasons why 
a mall could constitute a suitable place for this kind of sociability. Hopkins has identified the myths embodied in malls: the ideas of egalitarianism through consumption, personal transformation, millionaire status, and the myth of public community center.92 All these myths have a powerful appeal in contemporary South Africa where social inequality and widespread poverty add to the allure of these ideas. In fact, what applies in West Edmonton Mall, also applies to the V\&A:

enclosure is liberating yet confining; protection is reassuring yet encroaching; control is regulating yet potentially discriminating; space is diverse yet inflexible. The mega-mall is a community stage, yet stages community acts; it is at once both socially congregative (sociopetal) and divisive (sociofugal); it is public yet private. ${ }^{93}$

The Waterfront undeniably offers a safe and accessible haven for expressing new social identities, groundbreaking by virtue of their mere existence, as apartheid had strictly prohibited any such mixture of identities.

Outside the Waterfront and other malls, there are, however, very few spaces where these new social forms can be expressed, as the violence and insecurity that characterize present-day South African society and which still affect Blacks more than others, tend to make any spontaneous encounter threatening. ${ }^{94}$ At the Waterfront, there are elements that also symbolically include people of color; it is, after all, the gateway to Robben Island, the symbol of Black suffering, but also of White power overcome. The heavily contested information boards that were eventually erected to remind passers-by of the history of the place, its workers, fishermen, and prisoners are also symbolically important. ${ }^{95}$ The new Nobel Square capitalizes on the international image of Desmond Tutu and Nelson Mandela, but also pays homage to the four South Africans who received the Nobel Peace Prize - a sure proof of a troubled past. Here, the pain of racial segregation has not been ignored or glossed over as it has in the other malls of Cape Town, or in Grand West Casino. ${ }^{96}$ It is present and acknowledged, which makes the whole space much less abstract or homogenous. ${ }^{97}$

To add a final twist to this picture, Meaghan Morris has argued that malls 'are overwhelmingly and constitutively paradoxical' and that, '[t]o complicate matters, this dual quality is very much a part of [their] strategies of appeal, their "seductiveness", and also of their management of change. ${ }^{98}$ She uses the term 'ambivalence 99 to sum up this quality, and the V\&A Waterfront is indeed ambivalent in many ways. This ambivalence can be detected in occasional moments of violence, when the violence of exclusion appears on the stage that the Waterfront represents ${ }^{100}$ : it is not only a space where social and racial boundaries are (re)drawn, but also where political issues are contested. In the 1990s, skirmishes or larger-scale (national or city-wide) battles were fought there: we have already mentioned the 1993 and 1994 racial harassment of township shoppers. These skirmishes were quickly ended and in the wake of the first democratic election, the V\&A Waterfront management could not afford to alienate the African market. The Muslim vigilante group, PAGAD (People Against Gangsterism and Drugs) exploded a bomb in the V\&A Waterfront's Planet Hollywood, wounding two people on 1 January $1999 .{ }^{101}$ By taking the fight against gangsters and drugs into its own hands in the context of rising crime, the movement turned even more violent, and was said to be responsible for an array of bombings in the Cape Town area, targeting tourist and gay bars, as well as various outlets regarded as symbols of capitalist, western globalization.

Since the end of the 1990s, however, very few incidents have been recorded, and our field observations confirm that the nature of the social relations there is currently benign. This could 
be interpreted as a victory of neoliberal, consumerist attitudes. We suggest another interpretation: South Africa is a post-conflict society, and the framework (political, legal, social) regulating access to public space - in Staeheli and Mitchell's words, the 'regime of publicity'102 - is new and relatively consensual. Thus, the main event at play is a mixture of enactment and contestation: new, hard-won 'legitimate' identities are boldly displayed in a safe place. These new identities often combine race, class, and gender: the Waterfront is a place where one's identity as a woman - even dressed in a mini-skirt, something that recently led to abuse and assault at a Johannesburg taxi rank - doesn't mean a direct threat to one's physical safety. Being openly African, middle-class, and a consumer is a new statement with strong political undertones in a country where it was frowned upon, if not downright dangerous, 15 years ago.

\section{Publicization: theoretical implications}

Upper-class shoppers, street children, and maids in their Sunday best constitute the 'public' without which the Waterfront could not exist. This public happens to be multiracial, socially mixed, continuously generating various identities, and testing the boundaries of these particular identities. In this process, social spaces are constantly produced. The Waterfront's management does not entirely control this public and has to negotiate with it. The recent evolution of the Waterfront shows a dramatic increase in visitor diversity. Identities are being expressed, tried, and redefined. They are no longer the government's diktat, but are negotiated through a set of constraints (such as income or social norms - here, whiteness). Despite the various ambivalences that we have pointed out, the Waterfront becomes a place where it is indeed possible to test new social practices: shopping in a select, formerly White space, being a penniless flâneur in a shopping mall, being a parent and not only a racialized other. The diversity of the Waterfront crowd, and the opening of a plurality of uses and perspectives, to use Joseph's words again, are proofs that, over time, the Waterfront has become an increasingly public place socially. We suggest that this process of private spaces becoming more public should be called publicization.

With privatization receiving much more attention, the issue of publicization has generally been overlooked in urban studies. However, this one-sided focus on privatization has recently started drawing fire. Edward Soja deplores the 'tendency to see changes in public space simply as a kind of undemocratic transfer to the private domain. ${ }^{103}$ Moreover, recent literature points out that the emergence of public space - as we know it - has never been accidental or self-evident. On the contrary, it is the result of social and political processes, and often it has to be contested and conquered. Throughout history, those excluded and 'othered' - the working class, women, and people of color - have made claims to space. This has prompted Don Mitchell to argue that 'public space is thus socially produced through its use as public space.' ${ }^{\text {'04 }}$

Soja and Mitchell point out that public space should be approached by refocusing on processes, as well as their diversity. ${ }^{105}$ We also apply this suggestion to the notion of publicization. Since privatization is defined as the process through which a space is made more private, we can define the process of publicization as the process through which a space is made more public.

The notion of publicization has many applications in the field of urban studies, be it in other cities of the South, emerging countries, or even in the metropolises of the industrial North. When analyzing contemporary urban dynamics, we first have to ask: which new spaces are being publicized, how, and by whom? In South Africa, it is not just malls that are undergoing publicization. 
Parks, beaches, and places of worship are experiencing the same process to different degrees. The notion of publicization is thus helpful in uncovering the emerging forms of social cohesion and spatial 'togetherness.' 106 Second, publicization is definitely not a process unique to Cape Town or South Africa. Similar processes have been described in other cities. Guénola Capron, for example, has revealed how the decay of Argentina's public sphere and public spaces has led to the transfer of many social practices to the malls of Buenos Aires. ${ }^{107}$

Publicization also works at the three levels of public space identified earlier: the political, the juridical, and the social. ${ }^{108}$ At the political level, for instance, publicization occurs when franchise is extended and, in general, every time people gain more rights. In the juridical sense, a private space becomes publicized when the state acquires ownership of the land. Lastly, the process of publicization takes place socially when a significant, previously excluded, segment of the population gains physical access to a space. When assessing any space's degree of publicity, all three levels should be simultaneously taken into consideration. This also applies to privatization, which stems from the same dynamics as publicization. Privatization also needs to be considered and assessed at the political, juridical, and social levels. Consequently, publicization and privatization can occur simultaneously within a single space. In our case study, the V\&A Waterfront underwent juridical privatization in the sense that a private company now manages it. Nevertheless, it has also been undergoing social publicization, as it now hosts the diverse multitudes of Cape Town. We therefore maintain that the significant social changes in South Africa are not only being sustained, but also performed and amplified in that mall. In spite of all the negotiations and restrictions, the V\&A Waterfront is the best that Cape Town can currently offer in terms of social public space.

$[\mathrm{M}]$ alls are more than locations of consumption. Because of their secondary social and recreational roles, they represent a shared experience, a way of everyday life for most people. ${ }^{109}$

We have tried to argue here that, at the V\&A Waterfront, the social role of the mall may even be the principal one. Furthermore, a 'shared experience,' albeit in a mall, is a precious and rare occurrence in post-apartheid South Africa. In the words of Gilbert and Wood, such 'public spaces are not only important because they are the site of representation of a multicultural society, but rather because they test the relationships between members of such society. ${ }^{.110}$

The literature on malls has often emphasized the transfer in time and space that malls offer as cut off from the surrounding realities. But regardless of how salutary, even therapeutic this place can feel after the segregated reality of the surrounding city, it is more than just a fantasy - there is a large chunk of social reality being produced in the same environment. People do really encounter here, they do really interact, however fleetingly, on a more equal basis that has happened in decades, if ever. And the heavily commercial ideas of the developers and global retailers, the ambivalence and discomfort brought by insidious social norms are not the only influence on South African people's ideas. They have shown, time and again, that they are quite able to choose for themselves.

\section{Acknowledgements}

Jeanne Vivet helped to gather the empirical evidence used in this article, Hervé Parmentier drew the Figure 3 map. We wish to thank Robert Beauregard, Ilse Evertse, Anne Haila, Hille Koskela, Don Mitchell and 
particularly John Western for their thoughtful comments and expert advice. The constructive suggestions of the anonymous referees and the encouraging comments of the editor are also gratefully acknowledged. This work was funded by grants from the Academy of Finland, Ella and Georg Ehrnrooth Foundation, Institut Français d'Afrique du Sud (IFAS), French Ministry for Research (ACI n JC2069) and Oskar Öflund Foundation. The usual disclaimer applies.

\section{Biographical notes}

Myriam Houssay-Holzschuch is an associate professor in Geography at the University of Lyon, ENS LSH. She's been researching South African cities since 1994, and has notably published 'Mythologies territoriales en Afrique du Sud, un essai de géographie culturelle' (CNRS, 1996) and 'Le Cap, ville sudafricaine: ville blanche, vies noires' (L'Harmattan, 1999). She can be contacted at: University of Lyon, ENS LSH, UMR 5600 EVS, 15 Parvis René Descartes, BP 7000, 69342 Lyon cedex 07, France; email: Myriam.Houssay@normalesup.org

Annika Teppo is an adjunct professor in Urban Studies at the University of Helsinki, Department of Social Policy. She's been researching South African cities since 1997. She defended her PhD Thesis in Social Anthropology 'The Making of a Good White. A historical ethnography on the rehabilitation of poor Whites in a suburb of Cape Town' in 2004. She can be contacted at: Department of Social Policy, Urban studies, PO Box 18 (Snellmaninkatu 10), 00014 University of Helsinki, Finland; email: annika.teppo@helsinki.fi

\section{Notes}

1 See, for instance, Don Mitchell, Cultural geography: a critical introduction (Oxford; Malden, MA, Blackwell Publishers, 2000); David M. Smith, Moral geographies. Ethics in a world of difference (Edinburgh, Edinburgh University Press, 2000).

2 A.J. Christopher, The atlas of changing South Africa (London, Routledge, 2000).

3 For a summary of the apartheid city, see Ron J. Davies, 'The spatial formation of the South African city', GeoJournal, Sup. Iss., 2 (1981), pp. 59-72. For an insight into apartheid's control geographies in Cape Town, see John Western, Outcast Cape Town (Berkeley, CA, University of California Press, 1996); Myriam Houssay-Holzschuch, Le Cap, ville sud-africaine: Ville blanche, vies noires (Paris, L'Harmattan, 1999); Annika Teppo, The making of a good White. A historical ethnography of the rehabilitation of poor Whites in a suburb of Cape Town (Helsinki, University of Helsinki, 2004).

4 According to the Population Registration Act of 1950, every person was a member of a racial group: White, African or Coloured, later to be complemented with the fourth category of Indian. The grounds for this classification were related to physical appearance and general acceptance. This categorization was also hierarchical: Whites were regarded as the dominant group, and enjoyed many privileges, while Africans were in the worst position with Coloureds falling somewhere in between. The respective quality of the spaces allocated, even between African and Coloured townships, reflected this racist hierarchy. For a thorough explanation of racial categories, see A.J. Christopher, Atlas of Apartheid (Johannesburg, Witswatersrand University Press, 1994), p. 103-5. For the racial composition of Cape Town's population today, see Figure 3. In this paper, and while aware of the political implications of each term, we will follow the usual conventions and use the above categories as they are understood in the South African context.

5 Philippe Gervais-Lambony, 'Afrique du Sud, les temps du changement', Hérodote 111 (2003), pp. 81-98. 
6 Paul Williams and Ian Taylor, 'Neoliberalism and the political economy of the "new" South Africa', New political economy 5(1) (2000), pp. 21-40; S. Narsiah, 'Neoliberalism and privatisation in South Africa', GeoJournal 57 (2002), pp. 3-13; Gordon Pirie, "Reanimating a comatose goddess": reconfiguring central Cape Town', Urban forum 18(3) (2007), pp. 125-51.

7 Achille Mbembe and Sarah Nuttall, 'Writing the world from an African metropolis', Public culture 16(3) (2004), pp. 347-72.

8 Jenny Robinson, 'Inventions and interventions: transforming cities - an introduction', Urban studies 43(2) (2006), pp. 251-8, p. 251.

9 Ibid., p. 252.

10 Henri Lefebvre, Le Droit à la ville (Paris, Anthropos, 1968); Don Mitchell, The right to the city: social justice and the fight for public space (New York, Guilford Press, 2003).

11 Myriam Houssay-Holzschuch and Jeanne Vivet, 'Blurring the line: privatisation and publicisation at the Victoria \& Alfred Waterfront, Cape Town', in Claire Bénit, Seyi Fabiyi and Elisabeth Peyroux, eds, Privatisation of security in Sub-Sabaran African cities: urban dynamics and new forms of governance. Cape Town, Durban, Ibadan, Johannesburg, Kano, Lagos, Nairobi, Maputo, Windhoek (Johannesburg/Paris/IFAS/Kaithala, forthcoming).

12 See, for instance, Claudia Barril, Marion Carrel, Juan-Carlos Guerrero and Alicia Marquez, eds, Lepublic en action: usages et limites de la notion d'espace public en sciences sociales (Paris, L'Harmattan, 2003); Jean Baudrillard, ed., Citoyenneté et urbanité (Paris, Editions Esprit, 1991); René Collignon and Mamadou Diouf, eds, Les jeunes: hantise de l'espace public dans les sociétés du Sud (Paris, Éditions de l'Aube \& IRD, 2001).

13 Jürgen Habermas, Strukturwandel der Öffentlichkeit (Berlin, Luchterhand, 1962).

14 See, e.g. Craig J. Calhoun, Habermas and the public sphere (Cambridge, MA, MIT Press, 1992); Nancy Fraser, 'Rethinking the public sphere: a contribution to the critique of actually existing democracy', Social text 25/26 (1990), pp. 56-80; Tanni Haas, 'The public sphere as a sphere of publics: rethinking Habermas's theory of the public sphere', Journal of communication 54(1) (2004), pp. 178-84; Eric Laurier and Chris Philo, "A parcel of muddling muckworms": revisiting Habermas and the English coffeehouses', Social \& cultural geography 8(2) (2007), pp. 259-81; Mitchell, The right to the city.

15 Nicholas K. Blomley, Unsettling the city: urban land and the politics of property (New York, Routledge, 2004); Jean-Yves Toussaint and Monique Zimmerman, eds, User, observer, programmer et fabriquer l'espace public (Lausanne, Presses polytechniques et universitaires romandes, 2001).

16 Richard Sennett, The fall of public man (New York, Vintage Books, 1978).

17 Bruno Sabatier, La publicisation des espaces de consommation privés. Les complexes commerciaux récréatifs en France et an Mexique (Toulouse, Thèse de géographie, 2006).

18 See Isaac Joseph, Le Passant considérable, Essai sur la dispersion de l'espace public (Paris, Méridiens, 1984); Joseph, La ville sans qualités (La Tour d'Aigues, Éditions de l'Aube, 1998).

19 'une pluralité d'usages ou de perspectives', our translation. Joseph, La ville sans qualités, p. 34.

20 Don Mitchell and Lynn A. Staeheli, 'Clean and safe? Property redevelopment, public space, and homelessness in downtown San Diego', in Setha M. Low and Neil Smith, eds, The politics of public space (London, Routledge, 2006), pp. 143-75; Lynn A. Staeheli and Don Mitchell, The people's property? Power, politics and the public (New York, Routledge, 2007).

21 Staeheli and Mitchell, The people's property? Power, politics and the public.

22 Ibid., p. 141.

23 M.W. Swanson, 'The sanitation syndrome: bubonic plague and urban native policy in the Cape Colony, 1900-1909', The journal of African bistory XVIII(3) (1977), pp. 387-410.

24 See, for instance, Wayne Dooling, 'The making of a colonial elite: property, family and landed stability in the Cape Colony, c.1750-1834', Journal of Southern African studies 31(1) (2005), pp. 147-62.

25 Racially mixed neighborhoods where Whites and Coloureds lived together endured in Cape Town until the mid-1960s. Africans had to live in designated and racially homogeneous areas from 1910 onwards. 
26 Shamil Jeppie and Crain Soudien, eds, The struggle for District Six, past and present (Cape Town, Buchu, 1990).

27 Christopher, The atlas of changing South Africa.

28 Christopher, Atlas of apartheid.

29 Jeppie and Soudien, eds, The struggle for District Six, past and present.

30 Deborah Posel, The making of apartheid, 1948-1961: conflict and compromise (Oxford, Clarendon Press, 1991); Graham Watson, Passing for White: a study of racial assimilation in a South African school (London, New York, Tavistock Publications, 1970).

31 Heribert Adam and Kogila Moopley, The negotiated revolution. Society and politics in post-apartheid South Africa (Johannesburg, Jonathan Ball, 1993).

32 See, among others, Patrick Bond, Cities of gold, townships of coal: essays on South Africa's new urban crisis (Trenton, NJ, Africa World Press, 2000); Christoph Haferburg and Jürgen Oßenbrügge, eds, Ambiguous restructurings of post-apartheid Cape Town. The spatial form of socio-political change (Münster, LIT Verlag, 2003); Véronique Dupont and Myriam Houssay-Holzschuch, 'Fragmentation and access to the city: Cape Town and Delhi in a comparative perspective', in Philippe Gervais-Lambony, Frédéric Landy and Sophie Oldfield, eds, Reconfiguring identities and building territories in India and South Africa (Delhi, Manohar, 2005), pp. 277-314; Grant R. Saff, Changing Cape Town: urban dynamics, policy and planning during the political transition in South Africa (Lanham, MD, University Press of America, 1998); Jeremy Seekings, 'Are South Africa's cities changing? Evidence from the mid-1990s. Review essay', International journal of urban and regional research 27(1) (2003), pp. 197-202; Ivan Turok, 'Persistent polarisation post-apartheid? Progress towards urban integration in Cape Town', Urban studies 38(13) (2001), pp. 2349-77.

33 Guénola Capron, ed., Quand la ville se ferme, quartiers résidentiels sécurisés (Paris, Bréal, 2006); Karina Landman, 'Privatising public space in post-apartheid South African cities through neighbourhood enclosures', Geojournal 66 (2006), pp. 133-46.

34 A.J. Christopher, 'The slow pace of desegregation in South African cities, 1996-2001', Urban studies 42(12) (2005), pp. 2305-20; Anthony Lemon and David Clifford, 'Post-apartheid Transition in a Small South African Town: Interracial Property Transfer in Margate, KwaZulu-Natal', Urban studies 42(1) (2005), pp. 7-30.

35 Gervais-Lambony, 'Afrique du Sud, les temps du changement'.

36 Turok, 'Persistent polarisation post-Apartheid?'.

37 D. McDonald and L. Smith, 'Privatising Cape Town: from apartheid to neo-liberalism in the Mother City', Urban studies 41 (2004), pp. 1461-84, p. 1461. Narsiah, 'Neoliberalism and privatisation in South Africa', p. 3.

39 Williams and Taylor, 'Neoliberalism and the political economy of the "new" South Africa'.

40 Bond, Cities of gold, townships of coal; Vanessa Watson, Change and continuity in spatial planning: metropolitan, planning in Cape Town underpolitical transition (London, Routledge, 2002); McDonald and Smith, 'Privatising Cape Town', p. 1480.

41 Céline Vacchiani-Marcuzzo, Mondialisation et système de villes: les entreprises étrangères et l'évolution des agglomérations sud-africaines (Paris, Thèse de géographie, 2005).

42 Rafael Marks and Marco Bezzoli, 'Palaces of desire: Century City and the ambiguities of development', Urban forum 12(1) (2001), pp. 27-47; Noëleen Murray, Nick Shepherd and Martin Hall, Desire lines: space, memory and identity in the post-apartheid city (New York, Routledge, 2007). (plug-ins or connections - our translation) - mindful of not presupposing the existence of 'pure' cultures - help to unravel models, layout, and practices in these public spaces. See Homi Bhabha, The location of culture (London, Routledge, 1994); Ulf Hannerz, 'Sophiatown: the view from afar', Journal of Southern 
African studies 20 (2) (1994); Jean-Loup Amselle, Branchements. Anthropologie de l'universalité des cultures (Paris, Flammarion, 2001).

45 Mike Davis, City of quart:: excavating the future in Los Angeles (London; New York, Verso, 1990); Michael Sorkin, ed., Variations on a theme park: the new American city and the end of public space (New York, The Noonday Press, 1992).

46 Charlotte Lemanski, 'A new apartheid? The spatial implications of fear of crime in Cape Town, South Africa’, Environment \& urbanization 16(2) (2004), pp. 101-11.

47 English-speaking literature on the malls from this period includes prominent works such as Meaghan Morris, 'Things to do with shopping centres', in Susan Sheridan, ed., Grafts: feminist cultural criticism (London, New York, Verso, 1988), pp. 193-225; Jeffrey S.P. Hopkins, 'West Edmonton Mall as a centre for social interaction', The Canadian geographer 35(3) (1991), pp. 268-80; 'West Edmonton Mall: landscape of myths and elsewhereness', The Canadian geographer 34(1) (1990), pp. 2-17; Sorkin, ed., Variations on a Theme Park; Jon Goss, 'The magic of the mall: an analysis of form, function, and meaning in the contemporary retail built environment', Annals of the Association of American Geographers 83(1) (1993), pp. $18-47$.

48 Goss, 'The magic of the mall'.

49 Lynn A. Staeheli and Don Mitchell, 'USA's destiny? Regulating space and creating community in American shopping malls', Urban studies 43(5/6) (2006), pp. 977-92.

50 Mitchell, The right to the city; Staeheli and Mitchell, The people's property?

51 Shannon M. Jackson, 'Being and belonging: space and identity in Cape Town', Anthropology \& bumanism 28(1) (2003), pp. 61-84.

52 Marks and Bezzoli, 'Palaces of desire'; Murray et al., Desire lines.

53 Martin Hall and Pia Bombardella, 'Paths of nostalgia and desire through heritage destinations at the Cape of Good Hope', in Noëleen Murray et al., Desire lines, pp. 245-58; Clifford D. Shearing and Michael Kempa, The role of 'private security' in transitional democracies (Konrad Adenauer Stiftung, Johannesburg, 2001).

54 Goss, 'The magic of the mall', p. 18.

55 Hopkins, 'West Edmonton Mall as a centre for social interaction', p. 268-9.

56 Ibid., p. 273.

57 R. Birkby, The making of Cape Town's Victoria and Alfred Waterfront: the inside story of its planning, design, and creation (Cape Town, Victoria and Alfred Waterfront (Pty) Ltd, 1998).

58 http://www.waterfront.co.za/profile/company/introduction.php. Accessed 2 May 2008; Donwald Pressly, 'L\&R Consortium wins V\&A bid', Mail \& Guardian, 20 September 2006, at http:/ /www.mg.co. $\mathrm{za} /$ articlePage.aspx?articleId $=284607 \&$ area $=/$ breaking_news $/$ breaking_news_business $/$. Accessed 7 May 2008.

59 http://www.waterfront.co.za. Accessed 2 May 2008.

60 Christine Chivallon, N. Marne and D. Prost, 'Artefact de lieu et urbanité: le centre commercial interrogé', Les annales de la recherche urbaine 78 (1998), pp. 28-37; Goss, 'The magic of the mall'; Jon Goss, 'Onceupon-a-time in the commodity world: an unofficial guide to mall of America', Annals of the Association of American Geographers 89(1) (1999), pp. 45-75.

61 Houssay-Holzschuch and Vivet, 'Blurring the line'.

62 Such a Lefebvrian analysis of race and public space draws from Eugene J. McCann, 'Race, protest, and public space: contextualizing Lefebvre in the U.S. city', Antipode 31(2) (1999), pp. 163-84. McCann quotes and uses the Lefebvrian definition of abstract space, 'a space of quantification and growing homogeneity, a merchandised space where all the elements are exchangeable and thus interchangeable; a police space in which the state tolerates no resistance and no obstacles' from Henri Lefebvre, 'Space: social product and use value', in J.W. Freiberg, ed., Critical sociology: European perspectives (New York, Irvington, 1979), pp. 285-95, p. 293. 
63 Jeremy Seekings, 'The continuing salience of race: discrimination and diversity in South Africa', Journal of contemporary African studies 26(1) (2008), pp. 1 - 25.

Jeremy Seekings, “Just deserts": race, class and distributive justice in post-apartheid South Africa', Journal of Southern African studies 34(1) (2008), pp. 39-60, p. 40.

67 Louise Vincent, 'The limitations of "inter-racial contact": stories from young South Africa', Ethnic and racial studies (2008), pp. 1-26.

68 Despite our best efforts and repeated attempts between 2001 and 2005 to meet representatives of the V\& A Company head office, no interview has been granted.

69 Teppo, The making of a good White.

70 Vincent, "The limitations of "inter-racial contact".

71 Jonathan Manning, 'Racism in three dimensions: South African architecture and the ideology of white superiority', Social identities 10(4) (2004), pp. 527-36. Other authors share this interpretation: see for instance, Shearing and Kempa, The role of 'private security' in transitional democracies.

72 Simon Goudie, Daryll Killian and Belinda Dodson, 'Postmodern $\mathrm{f}(\mathrm{r})$ ictions: history, text and identity at the Victoria and Alfred Waterfront', Architecture SA (1995), pp. 26-31.

73 Nigel Worden and Elizabeth Van Heyningen, 'Signs of the times: tourism and public history at Cape Town's Victoria and Alfred Waterfront', Cabiers d'études africaines 141-142 (1996), pp. 215-36.

74 Sanette Ferreira and Gustav Visser, 'Creating an African Riviera: revisiting the impact of the Victoria and Alfred Waterfront development in Cape Town', Urban forum 18(3) (2007), pp. 227-46, p. 237.

75 Ibid., p. 240.

76 South Africa Tourism, http://www.tourismcapetown.co.za, accessed June 2006.

77 Authors' questionnaires.

78 All quotations are taken from the interviews conducted by Jeanne Vivet between January and April 2005.

79 Hopkins, 'West Edmonton Mall as a centre for social interaction', p. 273.

80 Joseph, Le Passant considérable, Essai sur la dispersion de l'espace public, Joseph, La ville sans qualités.

81 Morris, 'Things to do with shopping centres', p. 217.

82 Kay Anderson, "Race" in post-universalist perspective', Cultural geographies 15(2) (2008), pp. 155-71. See also, among many others, Ruth Frankenberg, White women, race matters: the social construction of whiteness (Minneapolis, University of Minnesota Press, 1993); John Hartigan, 'Establishing the fact of whiteness', American anthropologist 99(3) (1997), pp. 495-505. Goudie et al., 'Postmodern f(r)ictions'.

Belinda Dodson, 'Are we having fun yet? Leisure and consumption in the post-apartheid city', Tijdschrift voor economische and sociale geografie 91(4) (2000), pp. 412-25.

Arun Saldanha, Psychedelic white: Goa trance and the viscosity of race (Minneapolis, University of Minnesota Press, 2007).

Sarah Nuttall, 'Stylizing the self: the Y Generation in Rosebank, Johannesburg', Public culture 16(3) (2004), pp. 431-52; Elaine Salo, 'Negotiating gender and personhood in the new South Africa. Adolescent women and gangsters in Manenberg township on the Cape Flats', European journal of cultural studies 6(3) (2003), pp. 345-65; Gustav Visser, 'The homonormalisation of white heterosexual leisure spaces in Bloemfontein, South Africa', Geoforum 39(3) (2008), pp. 1347-61; Charlotte Bauer and Nosimilo Ndlovu, 'From rainbow nation to nutty nation', Mail \& Guardian 2008 at http://www.mg.co.za/article/200804-11-from-rainbow-nation-to-nutty-nation; Kopano Matlwa, Coconut: a novel (Auckland Park, South Africa, Jacana Media, 2007). 
89 Elijah Anderson, 'The cosmopolitan canopy', The annals of the American Academy of Political and Social Science 595 (2004), pp. 14-31, p. 15.

90 Eric Laurier and Chris Philo, The cappuccino community: cafés and civic life in the contemporary city (Economic \& Social Research Council \& University of Glasgow, 2005), pp. 11-15.

91 I.R.A. Bashkow, 'A Neo-Boasian conception of cultural boundaries', American anthropologist 106(3) (2004), pp. 443-58, p. 453.

92 Hopkins, 'West Edmonton Mall', p. 13.

93 Hopkins, 'West Edmonton Mall as a centre for social interaction', p. 277.

94 Ashley Dawson, 'Geography of fear: crime and the transformation of public space in post-apartheid South Africa', in Setha Low and Neil Smith, eds, The politics of public space (New York, Routledge, 2006), pp. 123-42; Lemanski, 'A new apartheid?', p. 105.

95 Nigel Worden, 'Contested heritage at the Cape Town waterfront', International journal of heritage studies 2(1\&2) (1996), pp. 59-75; Worden and Van Heyningen, 'Signs of the times'.

96 Murray et al., Desire lines.

97 McCann, 'Race, protest, and public space', p. 169.

98 Morris, 'Things to do with shopping centres', p. 195. Original emphasis.

99 Ibid., p. 197.

100 McCann, 'Race, protest, and public space', pp. 180-1.

101 Henri Boshoff, Anneli Botha and Martin Schönteich, Fear in the city, urban terrorism in South Africa (Institute for Security Studies, Cape Town, 2001).

102 Staeheli and Mitchell, The people's property?

103 Edward W. Soja, Postmetropolis: critical studies of cities and regions (Oxford; Malden, MA, Blackwell Publishers, 2000), p. 320.

104 Mitchell, The right to the city, p. 129. On the process of publicization, see also Bruno Latour and Peter Weibel, eds, Making things public, atmosphere of democracy (Karlsruhe / Cambridge, Massachusetts, ZKM (Zentrum für Kunst und Medientechnologie) / The MIT Press, 2005).

105 Henri Lefebvre, La production de l'espace (Paris, Anthopos, 1974); Lefebvre, Le Droit à la ville.

106 Wilmot Godfrey James, Phillip Dexter and David Chidester, What holds us together: social cohesion in South Africa (Pretoria / London, Human Sciences Research Council / Global, 2004).

107 Guénola Capron, 'Les centres commerciaux à Buenos Aires: les nouveaux espaces publics de la ville de la fin du XXe siècle', Les annales de la recherche urbaine 78 (1998), pp. 55-63.

108 Sabatier, La publicisation des espaces de consommation privés.

109 Hopkins, 'West Edmonton Mall'.

110 Patricia K. Wood and Liette Gilbert, 'Multiculturalism in Canada: accidental discourse, alternative vision, urban practice', International journal of urban and regional research 29(3) (2005), pp. 679-91. 